\title{
Johan Bellemans, MD, PhD: New Associate Editor
}

\author{
Jon Karlsson $\cdot$ Roland Becker $\cdot$ Neil Thomas
}

Published online: 22 May 2013

(C) Springer-Verlag Berlin Heidelberg 2013

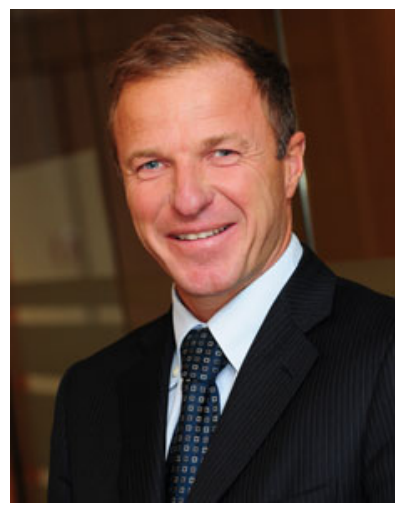

formation, he spent 3 years in centres in the UK and USA, where his vision on knee surgery was influenced by his teachers L. Whiteside (St. Louis, USA), R. Laskin (Hospital for Special Surgery, New York), and T. Rosenberg (Salt Lake City).

In 1995 he came back to Leuven to become staff member at the University Hospitals, where he was in charge of the unit for knee surgery and sports orthopaedics. He defended his $\mathrm{PhD}$ thesis on "Osseointegration in porous coated knee arthroplasty" in 1997 and was subsequently appointed Professor in Orthopaedics in 1998. In 2006 he was appointed Chairman of the Department of Orthopaedics and Traumatology.

Johan has been a member of ESSKA since 1997. He is a

Johan Bellemans, MD, PhD, has been appointed an Associate Editor of the Knee Surgery Sports Traumatology and Arthroscopy Journal commencing August 2013 and will replace Tassos Georgoulis. At the same time, we would like to thank Tassos for his outstanding services to the journal.

Johan has served the Journal for several years both as a reviewer and as an Editorial Board Member.

He trained at the Catholic University of Leuven in Belgium, graduating in 1989. During his orthopaedic

J. Karlsson ( $\square)$

Department of Orthopaedics, Sahlgrenska University Hospital, 43180 Mölndal, Sweden

e-mail: jon.karlsson@telia.com

R. Becker

Department of Orthopaedic and Traumatology, City Hospital Brandenburg, Hochstrasse 29, 14770 Brandenburg, Havel, Germany

\section{N. Thomas}

The Hampshire Clinic, Basing Road, Old Basing, Basingstoke, Hampshire RG24 7AL, UK past member of ESSKA's U45 committee and was selected in 1999 for the AAOSM-ESSKA Sports medicine Travelling Fellowship led by Prof. G. Puddu.

During the ESSKA presidency of Prof. Lars Engebretsen, Johan was chairman of the ESSKA Degenerative Knee Committee where he laid the basis for the foundation of European Knee Associates (EKA) together with Lars and Ate Wymenga. EKA is today a section of ESSKA and is currently presided by Prof. Jean-Noel Argenson. Johan is also a former president of the Belgian Knee Society, which is an ESSKA-affiliated society.

Johan's affinity with sports orthopaedics is through the Belgian Olympic Team, for which he was team physician at the Beijing and London Olympics in 2008 and 2012. He was also active as an Olympic athlete himself in the Barcelona games in 1992, where he took part in the sailing competition in the two-man 470 dinghy together with his brother.

Johan's current clinical practice and research activities include different aspects of sports-related knee pathology, the degenerative knee, and most importantly arthroplasty of the knee.

We welcome Johan to the team of KSSTA Editors. 